\title{
CHALLENGES ON ACCESSING FINANCE FOR MICRO-ENTERPRISES IN LATVIA
}

\author{
Ilona Beizitere1, PhD candidate/ researcher; Biruta Sloka², Dr.oec./ professor, senior \\ researcher; Ieva Brence ${ }^{3}$, Dr.sc.admin./ researcher; Elita Jermolajeva4, Dr.oec./ senior \\ researcher \\ ${ }^{1}$ Parliament of the Republic of Latvia, ${ }^{2}$ University of Latvia, ${ }^{3}$ Academy of Sciences, ${ }^{4}$ Latvia \\ University of Life Sciences and Technologies
}

\begin{abstract}
Financial support of companies for their development is considered and realised by many countries worldwide, also in Latvia. Latvia has been receiving critical remarks from entrepreneurs in regard to high level of refuse for financing from the financing institution ALTUM which is the principal intermediary of EU funds and provides resources to support entrepreneurship in Latvia. Statistical data indicate that there are significant reductions of micro-enterprises during recent years. The survey data showed that ALTUM rejected $39 \%$ of the surveyed micro-enterprises from those who had submitted applications within three years. In turn, only $6 \%$ of micro-enterprises have received full financing from banks or leasing companies. Funders rejected applications from $9 \%$ of micro-enterprises while another $5 \%$ themselves withdrew funding due to unacceptable conditions. Latvia has to address serious challenges in entrepreneurship development in regions in particular with a lower economic activity. The aim of the paper is to analyse situation of microenterprises for receiving funding. Research methods: analysis of scientific publications and results of previous conducted research, analysis of data obtained in survey of enterprises on questions of financing refuse and on evaluations related to financing conditions in recent years. For a more thorough data analysis (used evaluation scale 1-5) indicators of descriptive statistics are applied: indicators of central tendency or location - arithmetic means, mode, median; indicators of variability or dispersion - range, standard deviation, standard error of mean; cross - tabulations; testing of statistical hypotheses using t-test and analysis of variance - ANOVA; correlation analysis. Research results indicate that the use of more precise requirements of financing for micro-enterprises by finance institution ALTUM could benefit in better development of entrepreneurship in regions of Latvia.
\end{abstract}

Key words: micro-enterprises, requirements for financing, financing refuse, ALTUM, survey.

JEL code: G21, G23, L25, O16, R51.

\section{Introduction}

Scientific research worldwide indicate that important aspect is entrepreneurship financing using different financing schemes to support entrepreneurship development. Authorities in the Republic of Latvia (Saeima, 2014) have decided that the JSC Development Financial Institution Altum (ALTUM) has to support entrepreneurship development in Latvia. But Latvia has been receiving critical remarks from entrepreneurs in regard to high level of refuse for financing from the financing institution ALTUM which is the principal intermediary of EU funds and provides resources to support entrepreneurship in Latvia (Ministry of Economics ..., 2017). Statistical data (Central Statistical Bureau..., 2020) indicate that there are significant reductions in number of micro-enterprises during recent years and the business survey data showed that ALTUM rejected $39 \%$ of the surveyed micro-enterprises from those who had submitted applications within three years (Beizitere I, Brence I., 2020). In turn, only $6 \%$ of micro-enterprises have received full financing from banks or leasing companies. Funders rejected applications from $9 \%$ of micro-enterprises while another $5 \%$ themselves withdrew funding due to unacceptable conditions (Beizitere I, Brence I., 2020). Latvia has to address serious challenges in entrepreneurship development in regions in particular with a lower economic activity.

1 Parliament of the Republic of Latvia, Jekaba iela 11, Riga, Latvia, LV - 1811, Ilona.Beizitere@gmail.com

2 University of Latvia, Faculty of Business, Management and Economics, Institute of Economics and Management, Aspazijas bulv, 5, Riga, Latvia, LV - 1050,

Biruta.Sloka@lu.Iv

3 Academy of Sciences, Akademijas square 1, Riga, Latvia, LV - 1050, Ieva.Brence3@gmail.com

4 Latvia University of Life Sciences and Technologies, Faculty of Economics and Society Development, Svetes iela 18, Jelgava, Latvia, LV - 3000, Elita.Jermolajeva@gmail.com (corresponding author) 
The slow growth in lending could be partly attributed to weak demand for bank loans from the corporate sector in Latvia. This suggests that the desire of Latvian companies to invest in general is still moderate, even if they could finance investments with internal funds. Although non-bank lending is growing faster than bank lending, its share is too small to support corporate demand growth (OECD, 2019). In turn, the Bank of Latvia (2020) stated that the demand for loans from non-financial corporations decreased already in the second half of 2019. Lending policies pursued by credit institutions remained prudent throughout 2019 and early 2020.

The COVID-19 pandemic has highlighted the urgent need to consider financial sustainability, both within the financial system itself and in the role of capital and investors, in order to make economic and social systems more dynamic and resilient to external shocks (OECD, 2020). There are differences between countries in the proportion of SMEs applying for bank loans. The survey (Kwaak T., et al., 2020) indicated that in the period from April to September 2020 the share of SMEs applying for bank loans in Latvia was $15 \%$ or less. Moreover, many SMEs in Latvia (13\%) did not apply for bank loans due to the fear of rejection. In contrast, lending to SMEs by banks in other countries, even taking into account the constraints of COVID-19, such as Italy, Greece, France, Spain, Portugal and Lithuania, was higher than the EU-27 average of $35 \%$, well above the EU-27 average, and it was notably higher than the EU-27 average for 2019 (24\%) (Kwaak T. et al., 2020).

The study was conducted to investigate the challenges of access to finance for Latvian micro-enterprises that correspond to the classification of micro-enterprises in accordance with the European classification system (European Commission, 2003). The aim of the paper is to propose possible solutions for improvement of analyse situation of micro-enterprises to receive funding taking into account experience in other countries and suggestions by entrepreneurs. To investigate this, research methods were used: analysis of scientific publications and results of previous conducted research, analysis of data obtained in the survey of enterprises on questions of the funding refusal and on evaluations related to financing conditions in recent years.

The results of an ad hoc online survey (WAPI) conducted in early 2018 among companies registered in Latvia were used for in-depth analysis, in which the main financial sources used by entrepreneurs for business were identified, as well as the reasons why their requests were rejected. A computer-assisted internet interview (CAWI) questionnaire was sent to companies with publicly available email addresses. The questionnaire was addressed to those companies in the territory of Latvia that operate in sectors registered in the Latvian Register of Enterprises with 11 defined NACE2 codes that are eligible for state aid. Questionnaires from 2511 companies were accepted as valid, but 1879 of them were from microenterprises. The preliminary results showed an alarming picture. Despite the fact that companies need financing for their further development, the possibility to obtain financing is quite limited. In order to perform a more thorough analysis of the data in the survey, the entrepreneurs included in the sample of the survey were asked to assess various important aspects that have a significant impact on the development of the company (used evaluation scale 1-5). For survey data analysis indicators of descriptive statistics are applied: indicators of central tendency or location - arithmetic means, mode, median; indicators of variability or dispersion - range, standard deviation, standard error of mean; crosstabulations; testing of statistical hypotheses using t-test and analysis of variance - ANOVA; correlation analysis. 


\section{Theoretical findings}

Having an adequate number of sources of finance and easier access to them can help improve the performance of both the enterprise and the country (Civelek M. et al., 2019). One of the most serious problems limiting the development of small and micro enterprises is the financing of small and micro enterprises (Yan B., 2018), access to finance is crucial for the SMEs' growth and development. Academic researchers often discuss the issue of distinguishing micro-businesses from SMEs in their scientific discussions. The researchers drew conclusions by a systematic review of growth constraints and found that many studies used various definitions of micro-enterprises, which varied depending on the country in which the research was conducted and the existing legal framework (Gherhes C. et al., 2016). However, the landscape for entrepreneurial finance has changed strongly over the last years. Many new players have entered the arena (Block J. H. et al., 2017). Small and micro-enterprises are most affected during the COVID-19 epidemic period. Despite the government introducing many preferential policies, financing for small and micro-enterprises is still difficult (Yan X., Quan L., 2021).

Definitions of micro, small and medium-sized enterprises (MSMEs) vary from country to country depending on their economic structures. The commonly used parameters to define MSMEs at international level are the number of employees, total net assets, sales, paid-up capital, investment level, and annual turnover (Katoch G., 2020). Financing needs of micro-enterprises along their evolution are evaluated and discussed including aspects of using of non-formal sources as often formal financing sources are not available, indicating in the lack of knowledge for loan application preparation to the main reason (Prijadi $\mathrm{R}$. et al., 2020). For the last decade economists have been preoccupied with the decline in bank financing to small businesses and entrepreneurs (Fenwick M. et al., 2018), the SME financing types can not only be profiled according to their firm-, product-, industry- and country-specific characteristics but also to macroeconomic variables (Masiak C. et al., 2020). Alternative financing is an important type of financing for small and medium-sized innovative enterprises, as currently there are difficulties in obtaining financing from traditional sources (Chebukhanova L., Blokhina T., 2020). Once micro-enterprises can benefit from state aid only when they demonstrate that, at the time of the on-line completion of the business plan, they meet cumulatively the eligibility criteria imposed by the funding authority (Tirlea R. T., 2016). From other side, researchers ask also questions, like - if Business Administration degrees to encourage entrepreneurship and strengthen connection with business incubators (Alonso-Conde A. B. et al., 2020).

Several researchers state solid arguments on supporting entrepreneurs when it matters: optimising capital allocation for impact (Burton J., 2020; Okello Candiya Bongomin G., Ntayi J. M., 2020), thus concluding that needs for external financing are diverse and as well as diverse ways of obtaining this financing. Different sectors of the economy have different impacts of procurement strategies, for example, on construction SMEs' growth and have suggested that policy makers have to take into account needs and specific needs of different sectors of economy (Windapo A. O. et al., 2020).

Mobile money usage is becoming more and more often used world-wide as well as discussed and evaluated in the scientific publications by many researchers (Odoom R., Kosiba J.P., 2020). Researchers have underlined that there are differences of company financing by their size taking into account various types of risks and requiring needs for additional education to manage the companies (Md Husin M., Haron R., 2020). The research findings confirm that there is a correlation between the regions and the use of earnings to finance innovations by small and medium-sized enterprises. Thus, there are regions that differ greatly in whether SMEs finance innovations from their own sources. Moreover, a correlation between 
the regions and the use of the EU funds to finance innovation in small and medium-sized enterprises was confirmed (Koisova E. et al., 2018).

Research from China states that domestic and foreign small and micro enterprises have encountered great problems in financing, which caused by external and internal reasons. The most common internal reasons are mentioned: the majority of small and micro enterprises have small scale assets, fixed funds are not sufficient, financial aspects of the system is not perfect, the financial information is not true and transparent enough, the human resources are also very short, the management level is also low, and so on (An D. et al., 2018). Every market economy relies on the function of a financial intermediary to transfer resources from savers to investors (Zapalska A. M. et al., 2007). These types of aspects are becoming more and more important. The report of the European Commission (2017) states that taxes are one of the main tools available to the government to influence business to maximize its benefits. This study also indicates that there is a link between taxation and business. A number of relevant business choices that may be affected by the tax system are highlighted. Namely, taxes can influence not only the choice to become an entrepreneur, but also to invest and use internal or external financing in the company's operations.

A World Bank study (Jacobs B. et al., 2017) found that the tax regime for micro-enterprises in Latvia, adopted in 2010, provides strong incentives for companies to stay small to avoid financial indicators rising above the eligibility threshold. The Latvian government was advised to phase out the micro-enterprise tax regime, given its potentially negative impact on productivity growth. The regime could be replaced, for example, by a tax credit for new companies that reimburse corporate income tax payments or social security contributions for a certain period after their birth.

In addition, the OECD (2019) found that the proportion of companies subject to credit restrictions in Latvia is well above the EU average and also above the level seen in neighbouring countries (including Estonia and Lithuania). As in most OECD countries, access to credit for small businesses in Latvia was hampered by factors such as insufficient collateral and inadequate business history. Other indicators also point to the concerns of small businesses when applying for debt and using banking services. The proportion of Latvian companies that do not request bank financing due to a possible rejection or do not feel confident when it comes to bank financing is one of the highest in the EU (OECD, 2019).

\section{Empirical research results and discussion}

A survey of the company was conducted to find out the possibilities of companies in Latvia for the availability of financing and possible obstacles to obtaining external financing. Among the diverse obstacles to access to finance, in the questionnaire many entrepreneurs noted the tax burden. Thus, the task was to examine the relationship between the availability of financing and the tax burden according to the views of entrepreneurs, and the dependence on the size of companies, taking into account the number of employees. The main results of the survey of Latvian companies on the evaluations of entrepreneurs on the one hand about the level of availability of financing and on the other hand, the evaluations on tax burden by size of company depending on the number of employees are included in Table 1. 
The main statistical indicators of entrepreneurs' evaluations of the availability of financing and the tax burden by the number of employees in the company

\begin{tabular}{|c|c|c|c|}
\hline \multicolumn{2}{|c|}{ Number of employees in the company } & \multirow{2}{*}{$\begin{array}{c}\text { Availability of financing } \\
2.89\end{array}$} & \multirow{2}{*}{$\begin{array}{c}\text { Tax burden } \\
3.93\end{array}$} \\
\hline \multirow{6}{*}{ 1-4 employees } & Mean & & \\
\hline & $\mathrm{N}$ & 1413 & 1413 \\
\hline & Standard Deviation & 1.426 & 1.198 \\
\hline & Standard Error of Mean & 0.038 & 0.032 \\
\hline & Median & 3 & 4 \\
\hline & Range & 4 & 4 \\
\hline \multirow{6}{*}{ 5-9 employees } & Mean & 3.07 & 4.16 \\
\hline & $\mathrm{N}$ & 466 & 466 \\
\hline & Standard Deviation & 1.337 & 1.067 \\
\hline & Standard Error of Mean & 0.062 & 0.049 \\
\hline & Median & 3 & 5 \\
\hline & Range & 4 & 4 \\
\hline \multirow{6}{*}{$\begin{array}{c}10-49 \\
\text { employees }\end{array}$} & Mean & 2.98 & 3.95 \\
\hline & $\mathrm{N}$ & 477 & 477 \\
\hline & Standard Deviation & 1.319 & 1.113 \\
\hline & Standard Error of Mean & 0.060 & 0.051 \\
\hline & Median & 3 & 4 \\
\hline & Range & 4 & 4 \\
\hline \multirow{6}{*}{$\begin{array}{c}50-249 \\
\text { employees }\end{array}$} & Mean & 2.80 & 3.74 \\
\hline & $\mathrm{N}$ & 136 & 136 \\
\hline & Standard Deviation & 1.281 & 1.102 \\
\hline & Standard Error of Mean & 0.110 & 0.095 \\
\hline & Median & 3 & 4 \\
\hline & Range & 4 & 4 \\
\hline \multirow{6}{*}{ Total } & Mean & 2.94 & 3.97 \\
\hline & $\mathrm{N}$ & 2492 & 2492 \\
\hline & Standard Deviation & 1.383 & 1.157 \\
\hline & Standard Error of Mean & 0.028 & 0.023 \\
\hline & Median & 3 & 4 \\
\hline & Range & 4 & 4 \\
\hline
\end{tabular}

Source: author's calculations based on the survey of entrepreneurs, $n=2493$, evaluation scale 1-5, where 1- not limiting, 5 - limiting

In order to find out and estimate the differences in the assessments, a distribution of entrepreneurs' evaluations of the availability of financing by the number of employees in the company has been prepared and included in Table 2. 
Distribution of entrepreneurs' evaluations of the availability of financing by the number of employees in the company

\begin{tabular}{|c|c|c|c|c|c|}
\hline \multirow{2}{*}{ Evaluations } & \multicolumn{4}{|c|}{ Number of employees in the company } & \multirow{2}{*}{ Total } \\
\hline & $1-4$ & 5-9 & $10-49$ & $50-249$ & \\
\hline 1- not limiting & 338 & 81 & 81 & 27 & 527 \\
\hline$(2)$ & 236 & 71 & 96 & 28 & 431 \\
\hline (3) & 350 & 136 & 134 & 44 & 664 \\
\hline (4) & 219 & 91 & 85 & 19 & 414 \\
\hline 5 - limiting & 270 & 87 & 81 & 18 & 456 \\
\hline Total & 1413 & 466 & 477 & 136 & 2492 \\
\hline
\end{tabular}

Source: author's calculations based on the survey of entrepreneurs, $n=2493$, evaluation scale 1-5, where 1- not limiting, 5 - limiting

Analysis of variance (ANOVA) was used to evaluate the significance of differences in entrepreneurs' estimates depend on company size in terms of the availability of financing and tax burden, and the main results are presented in Table 3.

The main statistical indicators of testing statistical hypothesis with analysis of variance (ANOVA) on difference of entrepreneurs' evaluations by the number of employees in the company

\begin{tabular}{|c|c|c|c|c|c|c|}
\hline $\begin{array}{c}\text { Analysed } \\
\text { aspect }\end{array}$ & Sum of Squares & $\begin{array}{c}\text { Sum of Squares } \\
\text { (values) }\end{array}$ & df & $\begin{array}{c}\text { Mean } \\
\text { Square }\end{array}$ & F & Sig. \\
\hline \multirow{4}{*}{$\begin{array}{c}\text { Availability of } \\
\text { financing }\end{array}$} & Between Groups & 14.233 & 3 & 4.744 & 2.484 & 0.059 \\
\cline { 2 - 7 } & Within Groups & 4752.622 & 2488 & 1.910 & & \\
\cline { 2 - 7 } & Total & 4766.855 & 2491 & & & \\
\hline \multirow{3}{*}{ Tax burden } & Wetween Groups & 26.061 & 3 & 8.687 & 6.533 & 0.000 \\
\cline { 2 - 7 } & Within Groups & 3308.559 & 2488 & 1.330 & & \\
\cline { 2 - 8 } & Total & 3334.621 & 2491 & & & \\
\hline
\end{tabular}

Source: author's calculations based on the survey of entrepreneurs, $n=2493$, evaluation scale 1-5, where 1- not limiting, 5 - limiting

The results of analysis of variance have indicated that there is not a statistically significant difference in the evaluations of entrepreneurs by the size of the company on the tax burden (sig. 0.00). However, there is noticeable difference in entrepreneurs' assessments by company size regarding the availability of financing (sig. 0.059). Therefore, an additional correlation analysis was performed and the results are presented in Table 4. 
The main statistical indicators of correlations of entrepreneurs' evaluations of the availability of financing and the tax burden and the number of employees in the company

\begin{tabular}{|c|c|c|c|c|}
\hline $\begin{array}{c}\text { Analysed } \\
\text { aspect }\end{array}$ & $\begin{array}{c}\text { Statistical } \\
\text { indicators }\end{array}$ & $\begin{array}{c}\text { Availability of } \\
\text { financing }\end{array}$ & $\begin{array}{c}\text { Tax } \\
\text { burden }\end{array}$ & $\begin{array}{c}\text { Number of employees } \\
\text { in the company }\end{array}$ \\
\hline \multirow{2}{*}{$\begin{array}{c}\text { Availability } \\
\text { of financing }\end{array}$} & Pearson Correlation & 1 & $0.209 * *$ & 0.014 \\
\cline { 2 - 5 } & Sig. (2-tailed) & & 0.000 & 0.488 \\
\cline { 2 - 5 } & $\mathrm{N}$ & 2492 & 2492 & 2492 \\
\hline \multirow{2}{*}{ Tax burden } & Pearson Correlation & $0.209 * *$ & 1 & -0.007 \\
\cline { 2 - 5 } & Sig. (2-tailed) & 0.000 & & 0.723 \\
\cline { 2 - 5 } & $\mathrm{N}$ & 2492 & 2492 & 2492 \\
\hline \multirow{2}{*}{$\begin{array}{c}\text { Number of } \\
\text { employees in } \\
\text { the company }\end{array}$} & Pearson Correlation & 0.014 & -0.007 & 1 \\
\cline { 2 - 5 } & Sig. (2-tailed) & 0.488 & 0.723 & \\
\cline { 2 - 5 } & $\mathrm{N}$ & 2492 & 2492 & 2492 \\
\hline
\end{tabular}

** Correlation is significant at the 0.01 level (2-tailed).

Source: author's calculations based on the survey of entrepreneurs, $n=2493$, evaluation scale 1-5, where 1- not limiting, 5 - limiting

We were particularly interested in an in-depth analysis of the evaluations of entrepreneurs attributable to a micro-enterprise, i.e. with 9 employees or less. In order to find out whether there are differences in the evaluations of entrepreneurs between the size of micro-enterprises, depending on the number of employees, an additional analysis was performed.

To evaluate the significance of differences in evaluations by the company size in terms of the financing availability and the tax burden, it was applied an analysis of statistical hypotheses using t-test to evaluate the significance of those evaluations and the main results are included in Table 5. 
The main statistical indicators of testing statistical hypothesis with t-test on difference of entrepreneurs' evaluations of the availability of financing and the tax burden by the number of employees in the company

\begin{tabular}{|c|c|c|c|c|c|c|c|c|}
\hline $\begin{array}{l}\text { Analysed } \\
\text { aspect }\end{array}$ & \multicolumn{3}{|c|}{$\begin{array}{c}\text { Number of employees in the } \\
\text { company }\end{array}$} & $\mathbf{N}$ & Mean & $\begin{array}{l}\text { Standard } \\
\text { Deviation }\end{array}$ & \multicolumn{2}{|c|}{ Standard Error of Mean } \\
\hline \multirow{2}{*}{$\begin{array}{l}\text { Availability } \\
\text { of financing }\end{array}$} & \multicolumn{3}{|c|}{ 1-4 employees } & 1413 & 2.89 & 1.426 & \multicolumn{2}{|c|}{0.038} \\
\hline & \multicolumn{3}{|c|}{ 5-9 employees } & 466 & 3.07 & 1.337 & \multicolumn{2}{|c|}{0.062} \\
\hline \multirow{2}{*}{ Tax burden } & \multicolumn{3}{|c|}{ 1-4 employees } & 1413 & 3.93 & 1.198 & \multicolumn{2}{|c|}{0.032} \\
\hline & \multicolumn{3}{|c|}{ 5-9 employees } & 466 & 4.16 & 1.067 & \multicolumn{2}{|c|}{0.049} \\
\hline \multirow{2}{*}{$\begin{array}{l}\text { Analysed } \\
\text { aspect }\end{array}$} & \multirow[b]{2}{*}{ Variances } & \multicolumn{3}{|c|}{$\begin{array}{l}\text { Levene's Test for } \\
\text { Equality of Variances }\end{array}$} & \multicolumn{4}{|c|}{ t-test for Equality of Means } \\
\hline & & $\mathbf{F}$ & Sig. & $\mathbf{t}$ & df & $\begin{array}{c}\text { Sig. } \\
\text { (2-tailed) }\end{array}$ & $\begin{array}{c}\text { Mean } \\
\text { Difference }\end{array}$ & $\begin{array}{c}\text { Standard } \\
\text { Error } \\
\text { Difference }\end{array}$ \\
\hline \multirow{2}{*}{$\begin{array}{l}\text { Availability } \\
\text { of financing }\end{array}$} & $\begin{array}{c}\text { Equal } \\
\text { variances } \\
\text { assumed }\end{array}$ & 8.259 & 0.004 & -2.359 & 1877 & 0.018 & -0.177 & 0.075 \\
\hline & $\begin{array}{c}\text { Equal } \\
\text { variances not } \\
\text { assumed }\end{array}$ & & & -2.436 & 840.015 & 0.015 & -0.177 & 0.073 \\
\hline \multirow{2}{*}{ Tax burden } & $\begin{array}{c}\text { Equal } \\
\text { variances } \\
\text { assumed }\end{array}$ & 8.177 & 0.004 & -3.650 & 1877 & 0.000 & -0.227 & 0.062 \\
\hline & $\begin{array}{c}\text { Equal } \\
\text { variances not } \\
\text { assumed }\end{array}$ & & & -3.869 & 882.038 & 0.000 & -0.227 & 0.059 \\
\hline
\end{tabular}

Source: author's calculations based on the survey of entrepreneurs, $n=2493$, evaluation scale 1-5, where 1- not limiting, 5 - limiting

The results of the survey data analysis indicate that the differences in entrepreneur's evaluations by the company size do not differ statistically significant with significance level (sig. 0,018 and sig. 0,015) for entrepreneur's evaluations of the availability financing and with significance level $($ sig. 0,000$)$ for entrepreneur's evaluations of the tax burden.

In addition, the answers of entrepreneurs to the question of what were the unreasonable conditions for a company to acquire banks are considered. The main reasons mentioned by entrepreneurs for refusal of financing for SME and micro-enterprises are included in table 6. 
Table 6.

The main reasons for refusal of financing for SMEs and micro-enterprises in Latvia

\begin{tabular}{|c|c|c|c|}
\hline Reasons for refusal of financing & $\begin{array}{l}\text { Number of } \\
\text { companies } \\
\text { received } \\
\text { the } \\
\text { respective } \\
\text { refusal of } \\
\text { financing }\end{array}$ & $\begin{array}{l}\text { Share of } \\
\text { companies } \\
\text { received the } \\
\text { respective } \\
\text { refusal of } \\
\text { financing } \\
\text { (in \%) }\end{array}$ & $\begin{array}{c}\text { Share of enterprises } \\
\text { in the survey received } \\
\text { the respective refusal } \\
\text { of financing from all } \\
\text { companies with not } \\
\text { more than } \\
9 \text { employees (in \%) }\end{array}$ \\
\hline Bank required additional security & 69 & 3.7 & 70.4 \\
\hline Bank required guaranties by owners & 52 & 2.8 & 53.1 \\
\hline Bank required to subordinate owner's loan & 5 & 0.3 & 5.1 \\
\hline Bank required to increase own capital & 8 & 0.4 & 8.2 \\
\hline $\begin{array}{l}\text { Bank required to increase own contribution } \\
\text { in the project }\end{array}$ & 19 & 1.0 & 19.4 \\
\hline Bank restricts dividends & 7 & 0.4 & 7.1 \\
\hline Other reason (please, indicate) & 14 & 0.7 & 14.3 \\
\hline Hard to say & 9 & 0.5 & 9 \\
\hline Total number of refuses & 183 & & \\
\hline
\end{tabular}

Source: author's calculations based on the survey of entrepreneurs, $n=1879$

Most of the reasons given in the Table 6 show that banks with such conditions in order to provide financing to companies were trying to significantly reduce their level of credit risk.

Other unfulfillable and unacceptable conditions required by banks from the point of view of entrepreneurs representing micro-enterprises are summarized in Table 7. 
Other reasons for refusal of financing mentioned by entrepreneurs, by the number of employees of the company

\begin{tabular}{|l|c|c|}
\hline \multicolumn{1}{|c|}{ Responses } & \multicolumn{2}{c|}{$\begin{array}{c}\text { Number of } \\
\text { employees in } \\
\text { the company }\end{array}$} \\
\cline { 2 - 3 } & $\mathbf{1 - 4}$ & $\mathbf{5 - 9}$ \\
\hline High interest rate & 3 & 1 \\
\hline $\begin{array}{l}\text { Requested too much data, too many different statements and reports } \\
\text { that we couldn't complete }\end{array}$ & 2 & \\
\hline $\begin{array}{l}\text { The bank's offer was expensive and unprofitable for the company, I } \\
\text { provided the financing myself! }\end{array}$ & 1 & \\
\hline $\begin{array}{l}\text { Tax debt, notwithstanding the existence of an agreement with the tax } \\
\text { authorities on the gradual repayment of the debt }\end{array}$ & 1 & \\
\hline $\begin{array}{l}\text { It was necessary to indicate the exact future cash flow and positive } \\
\text { income now! }\end{array}$ & 1 & \\
\hline The valuation of the pledge was too different from its price & 1 & \\
\hline Banks believe that the countryside is not worth to finance & & 1 \\
\hline Various expensive activities & & 1 \\
\hline $\begin{array}{l}\text { The money received against the pledge or security is } \\
\text { disproportionately expensive, unprofitable }\end{array}$ & & 1 \\
\hline Due to the bank's poor customer service, we turned to another bank & & 1 \\
\hline Total number of responses from entrepreneurs of micro-enterprises & 9 & 5 \\
\hline
\end{tabular}

The various reasons given in Table 7 also suggest that banks are overly cautious about possible future losses when lending to micro-enterprises. In our point of view, this demonstrates the mistrust of banks in the business of micro-enterprises.

\section{Acknowledgements}

The paper is supported by National Research Programme INTERFRAME-LV.

\section{Conclusions, proposals, recommendations}

1) Entrepreneurs of micro-enterprises consider that in many cases financing availability and tax burden are limiting factors for their company development.

2) The entrepreneurs who consider financing availability and tax burden as limiting factors for their company development does not differ statistically by number of employees employed in the company.

3) For support from financing institution refusal reasons were that bank required additional security and bank required security by owners.

4) Aspects on refuse could be useful for practical studies by acting enterprises which will apply for financing support in future.

5) The government should carefully assess the impact of tax reform on the performance of enterprises, in particular micro-enterprises, in order to assess their ability to attract finance and invest in enterprises. It should be monitored whether this reform gives the expected benefits.

6) Given the prudence of banks in lending to companies and comparing the small share of non-banks in their financing, alternative channels for raising capital should be developed to support the demand of micro-enterprises and the possibilities for companies to receive public support should be expanded. 


\section{Bibliography}

1. Alonso-Conde, A.B., Rojo-Suarez, J., Rentas, S. (2020). Do Business Administration Degrees Encourage Entrepreneurship and Strengthen Connection with Business Incubators? On the Horizon, 28(4), pp. 153-163.

2. An, D., Li, J., Liu, M. (2018). Analysis of Financing Mode of Small and Micro Enterprises Based on Internet Finance. $2^{\text {nd }}$ International Conference on Social Sciences, Arts and Humanities (SSAH 2018), pp. 758-763.

3. Bank of Latvia (2020). Financial Stability Report 2020, Riga. Retrieved: https://datnes.latvijasbanka.Iv/fsp/FSP_2020_en.pdf. Access: 15.03.2021.

4. Beizitere, I, Brence, I. (2020). The Use of Public Financial Support: Study of Micro-Enterprises. Proceedings of the $21^{\text {th }}$ International Scientific Conference "Economic Science for Rural Development 2020", No 53, Jelgava, LLU ESAF, 12-15 May 2020, pp. 159-167.

5. Block, J.H., Colombo, M.G., Cumming, D.J. et al. (2018). New Players in Entrepreneurial Finance and why they are there. Small Business Economics, 50, pp. 239-250.

6. Burton, J. (2020). Supporting Entrepreneurs When it Matters: Optimising Capital Allocation for Impact. Journal of Entrepreneurship and Public Policy, 9(3), pp. 277-302.

7. Central Statistical Bureau of Latvia (2020). SRG030. Economically Active Enterprises of Market Sector in Statistical Regions, Cities and Counties by Size Group According to the Number of Employees and Main Economic Activity (NACE Rev. 2), Retrieved: http://data1.csb.gov.Iv/pxweb/en/uzn/uzn_01_skaits/?rxid=d8284c56-0641-451c-8b70b6297b58f464\&tablelisttrue. Access: 15.03.2021.

8. Chebukhanova, L., Blokhina, T. (2020). Problems of Alternative Financing for Innovative SME in Russia. Proceedings of INTCESS 2020- $7^{\text {th }}$ International Conference on Education and Social Sciences 20-22 January, 2020 - DUBAI (UAE).

9. Civelek, M., Kljucnikov, A., Kristofík, P., Rozsa, Z. (2019). Barriers in Financing Microenterprises from the Perspective of Czech and Slovak Microentrepreneurs. Journal of Business Economics and Management, 20(2), pp. 244-267.

10. Error! Hyperlink reference not valid.European Commission (2003). Commission Recommendation of 6 May 2003 Concerning the Definition of Micro, Small and Medium-sized Enterprises (Text with EEA Relevance) (Notified under Document Number C(2003) 1422). Official Journal L 124, 20.05.2003, pp. 36-41.

11. European Commission (2017). Literature Review on Taxation, Entrepreneurship and Collaborative Economy. Final Report. TAXUD/2016/DE/315, FWC No. TAXUD/2015/CC/131. Retrieved: https://ec.europa.eu/taxation_customs/sites/taxation/files/taxation_paper_70.pdf. Access: 21.03.2021.

12. Fenwick, M., McCahery, J.A., Vermeulen, E.P.M. (2018) Fintech and the Financing of SMEs and Entrepreneurs: From Crowdfunding to Marketplace Lending. In: Cumming D., Hornuf L. (eds) The Economics of Crowdfunding. Palgrave Macmillan, Cham.

13. Gherhes, C., Williams, N., Vorley, T., Vasconcelos, A.C. (2016). Distinguishing Micro-businesses from SMEs: a Systematic Review of Growth Constraints. Journal of Small Business and Enterprise Development, 23(4), pp. 939-963.

14. Jacobs, B. Sinnott, E., Skrok, E., Hazans, M., Mosberger, P., Pluta, A., Rastrigina, O., Dillinger, W.R. (2017), Latvia Tax Review, World Bank Group, Washington, D.C.

15. Katoch, G. (2018). Financing of Microenterprises: Access and Sustainability. Journal of Entrepreneurship and Management, 7(2), pp. 28-40.

16. Koisova, E., Grmanova, E., Habanik, J. (2018). Regional Disparities in Financing Innovations in Small and Medium-Sized Enterprises. Journal of International Studies, 11(3), pp. 124-136.

17. Kwaak, T., Cheikh, N., Clarke, M., Snijders, J. (2020). Survey on the Access to Finance of Enterprises (SAFE). Analytical Report 2020. November 2020. European Commission.

18. Masiak, C., Moritz, A., Lang, F. (2020). European SME Financing: An Empirical Taxonomy. In: Moritz A., Block J., Golla S., Werner A. (eds) Contemporary Developments in Entrepreneurial Finance. FGF Studies in Small Business and Entrepreneurship.

19. Md Husin, M., Haron, R. (2020). Micro, Small and Medium Enterprises' Competitiveness and Micro-takaful Adoption. ISRA International Journal of Islamic Finance, 12(3), pp. 367-380.

20. Ministry of Economics of the Republic of Latvia (2017). An Updated Market Gap Assessment in the Field of Financial Accessibility: Progress Report on Implementation of Financial Instrument Programs. Riga, 2017. Retrieved: https://www.em.gov.Iv/lv/media/4277/download. Access: 24.03.2021

21. Odoom, R. Kosiba, J.P. (2020). Mobile Money Usage and Continuance Intention among Micro Enterprises in an Emerging Market - the Mediating Role of Agent Credibility. Journal of Systems and Information Technology, 22(1), pp. 97-117.

22. OECD (2020), OECD Business and Finance Outlook 2020: Sustainable and Resilient Finance, OECD Publishing, Paris.

23. OECD (2019). OECD Economic Surveys: Latvia. May 2019, Overview. OECD Publishing, Paris.

24. Okello Candiya Bongomin, G., Ntayi, J.M. (2020). Mobile Money Adoption and Usage and Financial Inclusion: Mediating Effect of Digital Consumer Protection. Digital Policy, Regulation and Governance, 22(3), pp. 157-176.

25. Prijadi, R., Wulandari, P., Desiana, P.M., Pinagara, F.A., Novita, M. (2020). Financing Needs of MicroEnterprises along their Evolution. International Journal of Ethics and Systems, 36(2), pp. 263-284. 
26. Saeima of the Republic of Latvia (Saeima) (2014). Attistibas Finansu Institucijas Likums/ The Law on Development Financial Institution. Latvijas Vestnesis, 15.11.2014., Nr. 228 (5288).

27. Tirlea, R.T. (2016). Financing Alternatives of Micro Enterprises (II Practical Application). The $21^{\text {st }}$ International Conference on Knowledge Organisation Proceedings.

28. Windapo, A.O., Olugboyega, O., Odediran, S. (2020). Impacts of Procurement Strategies on Construction SMEs' Growth. Journal of Financial Management of Property and Construction, 25(3), pp. 423-446.

29. Yan, B. (2018). Internet Finance and the Innovation of Financing Mode of Small and Micro Enterprises. 2018 International Conference on Economics, Politics and Business Management (ICEPBM 2018), pp. 314-318.

30. Yun, X., Quan, L. (2021). Research on Financing of Small and Micro Enterprises in Postepidemic Period: Based on Evolutionary Game and Numerical Simulation, Mathematical Problems in Engineering, vol. 2021, Article ID 4796485, 7 pages.

31. Zapalska, A.M., Brozik, D., Rudd, D. (2007). The Success of Micro-Financing, Problems and Perspectives in Management, 5(4), pp. 84-90. 